\title{
Respon Morfologi Tanaman Jagung (Zea mays) Varietas Bisma dan Srikandi Kuning pada Kondisi Cekaman Salinitas Tinggi
}

\author{
Rossy Angelina Latuharhary dan Triono Bagus Saputro \\ Departemen Biologi, Fakultas Ilmu Alam, Institut Teknologi Sepuluh Nopember (ITS) \\ e-mail: trionobsaputro@bio.its.ac.id
}

\begin{abstract}
Abstrak-Cekaman salinitas merupakan salah satu cekaman abiotik yangdapat mengakibatkan kematian tanaman. Pada penelitian ini digunakan metode seleksi secara in vivo untuk perlakuan cekaman salinitas. Pada penelitian ini digunakan pengamatan morfologi untuk mengetahui respon adaptasi dan ekspresi gen-spesifik pada jagung terhadap kondisi dengan cekaman salinitas. Varietas jagung yang digunakan pada penelitian ini adalah jagung varietas Bisma dan Srikandi Kuning. Tujuan penelitian ini yaitu untuk mengetahui interaksi antara varietas dan konsentrasi $\mathrm{NaCl}$ terhadap pertumbuhan tanaman Zea mays. Metode yang digunakan yaitu pengamatan tinggi tanaman, luas daun, panjang akar, berat kering, dan berat basah. Hasil dari morfologi akibat perlakuan $\mathrm{NaCl}$ pada varietas Bisma dan Srikandi Kuning terendah terjadi pada konsentrasi 10.000 ppm yaitu tinggi tanaman Srikandi Kuning $7,73 \mathrm{~cm}$ dan Bisma $5,76 \mathrm{~cm}$, luas daun $11,98 \mathrm{~mm}^{2}$ dan bisma $11,98 \mathrm{~mm}^{2}$, berat basah Srikandi Kuning 2,38 gram dan Bisma 1,91 gram, berat kering Srikandi Kuning 0,16 gram, panjang akar Srikandi Kuning 7,84 cm dan Bisma 4,53 cm. Kesimpulan dari penelitian ini adalah memberikan informasi tentang pertumbuhan tanaman jagung (Zea mays L.) varietas Bisma dan Srikandi Kuning pada kondisi salinitas tinggi serta galur hasil seleksi dapat digunakan secara lebih lanjut dalam perakitan varietas tahan salinitas yakni sebagai tetua persilangan.
\end{abstract}

Kata Kunci-Cekaman Salinitas, Jagung, Morfologi.

\section{PENDAHULUAN}

$\mathrm{T}$ ANAMAN jagung (Zea mays L.) merupakan salah satu bahan pangan pokok potensial dan menjadi salah satu komoditas penting dalam agribisnis [1]. Hasil panen tanaman jagung penting dalam upaya peningkatan ekonomi agrikultur dan agribisnis dunia [2]. Produksi tanaman jagung pada tahun 2004 mengalami peningkatan sekitar 2,43\%, namun tidak seimbang dengan kebutuhan jagung yang semakin meningkat, terkait dengan tingkat pemanfaatannya yang luas di berbagai industri. Hal ini, diperparah dengan adanya konversi lahan pertanian menjadi area perumahan, sehingga luasan lahan produksi semakin sempit [3].

Peningkatan produksi pertanian dapat dipecahkan dengan memanfaatkan lahan marginal. Lahan marginal di dunia meliputi "salt marshes" di daerah kering dan daerah pasang surut (mangrove swamps), baik pada wilayah subtropik dan tropik.Indonesia sebagai negara kepulauan yang berjumlah 17.508 pulau, mempunyai wilayah pantai cukup luas dengan aneka manfaat bagi kehidupan manusia [4]. Pada lahan salin, konsentrasi garam-garam terlarut akan terakumulasi secara berlebihan dalam tanaman yang dapat menyebabkan cekaman salinitas pada tanaman. Cekaman salinitas merupakan salah satu cekaman abiotik yang cukup serius pada tanaman [5]. Cekaman salinitas dapat mempengaruhi pertumbuhan dan fisiologis tanaman, juga aktivitas biokimia seperti aktivitas fotosintesis dan komponen klorofil [6]. Salinitas juga merupakan salah satu faktor pembatas yang mampu menyebabkan menurunnya produktivitas tanaman, serta pada tingkat konsentrasi tertentu dapat mengakibatkan kematian tanaman [6] dan jagung termasuk tanaman yang cukup sensitif terhadap cekaman salinitas [7].

Varietas jagung yang digunakan pada penelitian ini adalah jagung varietas Bisma dan Srikandi Kuning. Varietas Bisma mempunyai keunggulan yaitu memiliki potensi hasil 7,0 - 7,5 t/ha pipilan kering, memiliki ketahanan terhadap penyakit karat dan bercak daun. Sedangkan varietas srikandi kuning mempunyai keunggulan Ketahanan penyakit tahan hawar daun Harpophora maydis dan karat daun Puccinia sp, sedikit rentan hama penggerek batang (Ostrinia furnacalis) dan jagung varietas srikandi ini dianjurkan ditanam di dataran rendah [8]. Pada varietas Bisma dan Srikandi Kuning belum banyak penelitian tentang ketahanan terhadap kondisi salinitas tinggi sehingga perlu dilakukan penelitian terhadap tingkat ketahanan terhadap kondisi salinitas.

Pada penelitian ini digunakan metode seleksi secara in vivo untuk perlakuan cekaman salinitas. Pendekatan morfologi dilakukan untuk mengetahui respon adaptasi dan ekspresi genspesifik pada jagung terhadap kondisi dengan cekaman salinitas [9]. Ketika terjadi cekaman salinitas, maka akan menyebabkan konformasi suatu gen yang menyebabkan perubahan morfologi, fisiologi, aktivitas biokimia pada tanaman sebagai respon adaptasi untuk pertahanan, misalnya luas daun dan berat basah yang berkurang [10].

Tanaman yang mengalami cekaman dapat dideteksi tingkat ketahananya berdasarkan morfologi. Oleh sebab itu, penelitian ini dilakukan bertujuan untuk melihat ketahanan jagung varietas Bisma dan Srikandi Kuning melalui pengamatan morfologi pada tanaman jagung lokal yang tercekam salinitas tinggi.

\section{METODOLOGI}

\section{A. Pemecahan Dormansi Benih}

Benih jagung varietas Srikandi Kuning dan Bisma direndam dalam air selama 6 jam dalam dua wadah yang berbeda untuk memecahkan dormansi biji sekaligus untuk membedakan 
antara benih yang baik dengan yang tidak. Benih yang digunakan selanjutnya adalah benih yang tenggelam karena benih yang tenggelam mengindikasikan benih tersebut memiliki anatomi yang lengkap.

\section{B. Penanaman Benih Jagung}

Tanah dicampurkan dengan kompos kemudian dimasukkan ke dalam pot ray. Benih jagung disemai pada pot ray untuk menyeleksi benih yang tumbuh. Setelah itu, masing-masing benih varietas jagung yang telah tumbuh 2 daun diambil sebanyak 9 biji dan dipindahkan ke polybag berukuran 1/2 kgberukuran $1 / 2 \mathrm{~kg}$ yang telah berisi tanah: kompos 3:1. Pada bagian bawah masing-masing polybag berukuran 1/2 $\mathrm{kg}$ diberikan wadah. Tanaman dilakukan pencekaman selama 14 hari. Waktu yang telah ditentukan yaitu selama 14 hari setelah pencekaman garam tinggi, menyebabkan terjadinya akumuasi ABA [11]. Selain itu, pada 14 hari ketika tercekam $\mathrm{NaCl}$, terjadi akumulasi hormon SA dan JA [11].

Akumulasi hormon ABA akan menginduksi gen responsif Osr40C1. Gen Osr40c lberfungsi mengkode protein responsif terhadap cekaman salinitas, yang akan berperan untuk mencegah kehilangan air dan mempertahankan rigiditas dinding sel [10] serta sebagai detoksifikasi ROS (reactive oxygen species) untuk mengurangi efek racun dari ROS dan juga dapat menghambat terjadi kelayuan tanaman akibat cekaman salinitas, sehingga dapat meningkatkan toleransi tanaman terhadap cekaman salinitas [4]. Konsentrasi $\mathrm{NaCl}$ yang digunakan dalam penelitian ini adalah 0, 5000, dan 10000 ppm dalam $100 \mathrm{ml}$ air dengan pengulangan sebanyak 3 kali. Sedangkan benih yang digunakan merupakan 2 jenis varietas berbeda yakni jagung Bisma dan Srikandi Kuning. Sehingga jumlah total benih yang ditanam berjumlah 18 .

Tabel 1

Kategori EC

\begin{tabular}{cc}
\hline \hline EC (Electron Condictivity) & Category Salinity \\
\hline$<4 \mathrm{ds} / \mathrm{m}$ & Low \\
$4-8 \mathrm{ds} / \mathrm{m}$ & Moderate \\
$>8 \mathrm{ds} / \mathrm{m}$ & High \\
\hline \hline
\end{tabular}

Konsentrasi $\mathrm{NaCl}$ yang digunakan dalam penelitian ini adalah 0, 5000, dan $10000 \mathrm{ppm}$ sudah termasuk dalam kategori salinitas tinggi dimana nilai EC $1 \mathrm{ds} / \mathrm{m}$ sama dengan 500 ppm, didapat dari convertion chart EC to ppm [4].

\section{Pengamatan Tinggi Tanaman}

Pengamatan tinggi tanaman dilakukan dengan cara mengukur bagian aereal tanaman dari bagian pangkal batang hingga pucuk daun tertinggi dengan menggunakan penggaris.

\section{Pengamatan Luas Daun}

Luas daun ditetapkan dengan metode gravimetri, yaitu dengan cara daun digambar dan ditaksir luasnya pada sehelai kertas dengan mengukur perbandingan berat replika daun dengan berat total kertas dengan rumus sebagai berikut :

$$
\mathrm{LD}=\frac{\mathrm{Wr}}{\mathrm{Wt}} \quad \mathrm{X} \mathrm{LK}
$$

LD: Luas daun $\left(\mathrm{cm}^{2}\right)$

LK: Luas total kertas $\left(\mathrm{cm}^{2}\right)$

\section{E. Pengamatan Panjang Akar}

Pengukuran panjang akar dilakukan setelah perlakuan cekaman selesai dilakukan, kemudian diukur dari pangkal akar hingga ujung akar terpanjangdengan menggunakan jangka sorong.

\section{F. Pengamatan Berat Kering}

Semuabagian tanaman dicuci bersih dan dikeringkan, kemudian dimasukkan kedalam oven pada suhu $110^{\circ} \mathrm{C}$ sampai didapatkan berat yang konstan.

\section{G. Pengamatan Berat Basah}

Semua bagian tanaman dicuci bersih dan ditimbang dengan neraca analitik.

\section{H. Rancangan Penelitian}

Penelitian ini menggunakan Rancangan Acak Lengkap (RAL) dan dilakukan pengulangan sebanyak 3 kali, sehingga total unit percobaan sebanyak 18 polybag berukuran $1 / 2 \mathrm{~kg}$. Pengamatan dilakukan selama 14 hari perlakuan setelah benih tumbuh 2 daun pertama.Data hasil pengamatan parameter morfologi jagung dianalisis dengan analisis statistik yaitu uji ANOVA (Analysis of Variance) faktorialpada taraf kepercayaan $95 \%$. Hipotesis yang digunakan adalah sebagai berikut:

$\mathrm{H}_{0}$ : variasi konsentrasi $\mathrm{NaCl}$ tidak berpengaruh terhadap morfologi jagung

$\mathrm{H}_{1}$ : variasi konsentrasi $\mathrm{NaCl}$ berpengaruh terhadap morfologi jagung

Jika terdapat satu perlakuan atau lebih yang memberikan hasil berbeda nyata dengan kontrol maka $\mathrm{H}_{0}$ ditolak atau konsentrasi $\mathrm{NaCl}$ yang berbeda memberi pengaruh terhadap morfologi tanaman. Jika $\mathrm{H}_{0}$ maka dilakukan uji Tukey pada taraf 5\%, dengan menggunakan program Minitab Statistical Software. Data hasil pengamatan morfologi tanaman, persentase tanaman hidup dan analisis ekspresi genakan di analisis secara deskriptif.

\section{PEMBAHASAN}

Tanaman jagung yang digunakan pada penelitian ini memiliki morfologi yang relatif sama. Kesamaan morfologi meliputi tinggi tanaman yaitu $15 \mathrm{~cm}$ serta memiliki 2 daun. Selanjutnya dipindahkan ke media tanah yang telah mengandung $\mathrm{NaCl}$ konsentrasi 0, 5000, 10.000 ppm. Kondisi morfologi dari masing-masing varietas didapatkan hasil setelah 14 hari di media tanah yang telah mengandung $\mathrm{NaCl}$ konsentrasi 0, 5000, 10.000 ppm (Gambar 1 dan 2).

Pada penelitian ini varietas Srikandi Kuning dan Bisma memberikan respon yang berpeñ garuh terhadap $\mathrm{NaCl} 5000$ ppm dan 10.000 ppm. Empat belas hari masa perlakuan menyebabkan terjadinya akumulasi ABA yang berperan dalam persinyalan pertahanan pada penurunan tekanan turgor [9]. ABA memicupertukaran ion $\mathrm{Ca}^{2+}$ serta pengeluaran anion dan ion $\mathrm{K}^{+}$. ABA dapat menyebabkan penurunan tekanan turgor pada sel penjaga, sehingga menyebabkan penutupan stomata [12]. Selain itu, perlakuan $\mathrm{NaCl}$ akan menginduksi akumulasi hormon Asam Salisilat dan Asam Jasmonat [7]. Berdasarkan [13] secara in vitro kalus Manding yang dicekam $\mathrm{NaCl}$ 
memiliki warna kuning-kecokelatan hingga cokelat muda dengan tekstur remah hingga intermediet dan kalus Bluto, memiliki warna putih-kekuningan hingga putih-kecokelatan dengan tekstur remah hingga kompak. Perbedaan morfologi tersebut, merupakan suatu bentuk respon terhadap adanya cekaman $\mathrm{NaCl}$.

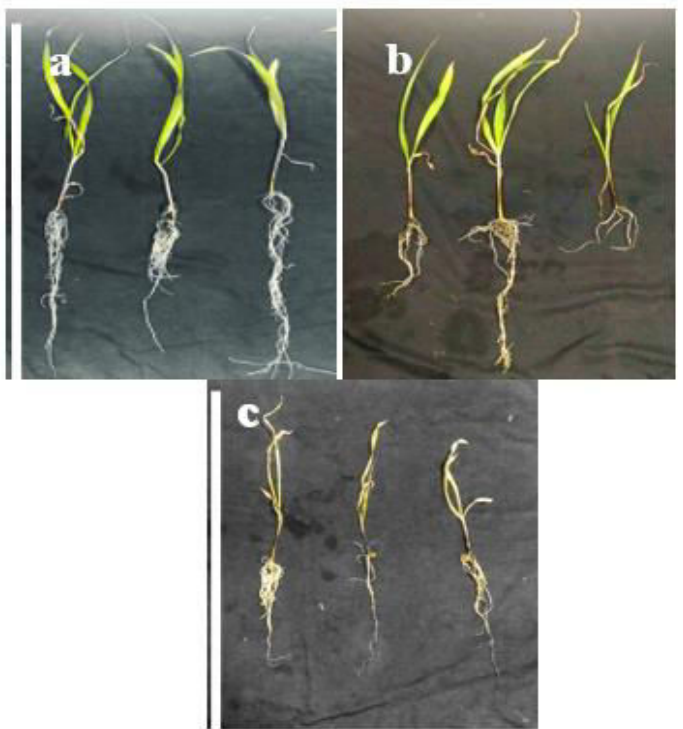

Gambar 1. Morfologi Bisma. Keterangan: a) 0 ppm. b) 5000 ppm. c)10000 ppm. Penanda $30 \mathrm{~cm}$.

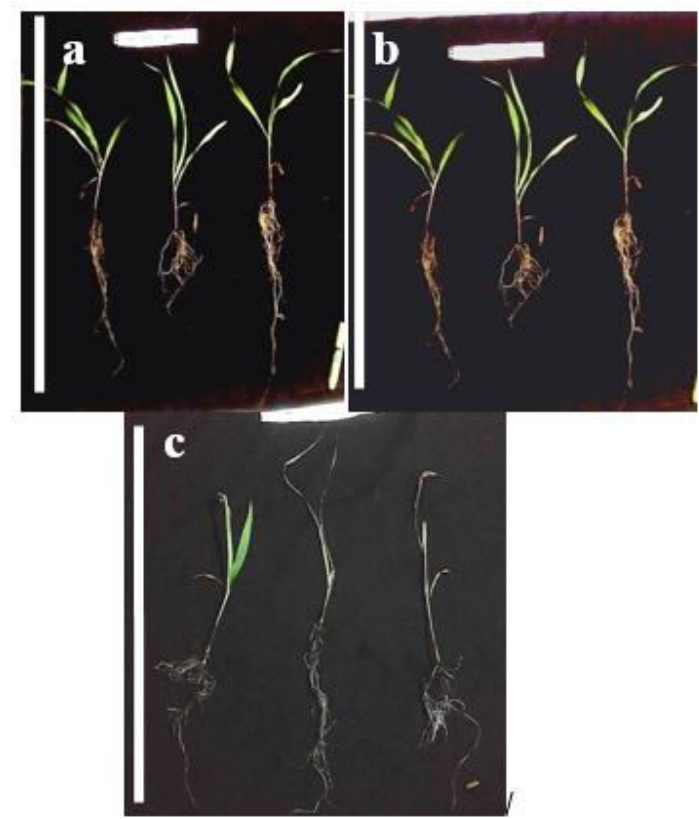

Gambar 2. Morfologi Srikandi Kuning Keterangan: a) 0 ppm. b) 5000 ppm. c) $10000 \mathrm{ppm}$, penanda $30 \mathrm{~cm}$.

Berdasarkan hasil analisis ANOVAFactorial yaitu $\mathrm{p}$ value sebesar 0,000 ( $\mathrm{p}$ value < 0,05), menunjukkan bahwa perlakuan konsentrasi $\mathrm{NaCl}$ berpengaruh terhadap pertambahan tinggi tanaman, luas daun, berat kering, berat basah, dan panjang akar. Pengaruh variasi konsentrasi $\mathrm{NaCl}$ terhadap pertambahan tinggi tanaman varietas Srikandi Kuning dan Bisma ditunjukkan pada Tabel 2, pertambahan luas daun Tabel 3, pertambahan panjang akar Tabel 4, pertambahan berat basah Tabel 5 dan pertambahan berat kering Tabel 6.
Tabel 2.

Analisis Pengaruh Interaksi Variasi Konsentrasi $\mathrm{NaCl}$ terhadap tinggi tanaman Z. mays

\begin{tabular}{ccc}
\hline \hline Varietas & $\begin{array}{c}\text { Konsentrasi NaCl } \\
(\mathrm{ppm})\end{array}$ & $\begin{array}{c}\text { Pertambahan Tinggi } \\
\text { Tanaman }\end{array}$ \\
\hline \multirow{3}{*}{ Srikandi Kuning } & 0 & $23.1433 \mathrm{a}$ \\
& 5000 & $18.6400 \mathrm{a}$ \\
Bisma & 10000 & $7.7300 \mathrm{~b}$ \\
& 0 & $24.5167 \mathrm{a}$ \\
& 5000 & $19.4433 \mathrm{~b}$ \\
\hline \hline
\end{tabular}

Tabel 3.

Analisis Pengaruh Interaksi Variasi Konsentrasi $\mathrm{NaCl}$ terhadap luas daun $\mathrm{Z}$. mays

\begin{tabular}{ccc}
\hline Varietas & $\begin{array}{c}\text { Konsentrasi NaCl } \\
(\mathrm{ppm})\end{array}$ & $\begin{array}{c}\text { Pertambahan Luas } \\
\text { Daun }\end{array}$ \\
\hline \multirow{2}{*}{ Srikandi Kuning } & 0 & $68,45 \mathrm{a}$ \\
& 5000 & $51,34 \mathrm{~b}$ \\
& 10.000 & $11,98 \mathrm{c}$ \\
Bisma & 0 & $58,165 \mathrm{a}$ \\
& 5000 & $51,34 \mathrm{~b}$ \\
\hline \hline
\end{tabular}

Tabel 4.

Analisis Pengaruh Interaksi Variasi Konsentrasi $\mathrm{NaCl}$ terhadap panjang akar Z. mays

\begin{tabular}{ccc}
\hline \hline \multirow{2}{*}{ Varietas } & $\begin{array}{c}\text { Konsentrasi NaCl } \\
(\mathrm{ppm})\end{array}$ & $\begin{array}{c}\text { Pertambahan } \\
\text { Panjang Akar }\end{array}$ \\
\hline \multirow{2}{*}{ Srikandi Kuning } & 0 & $23,29 \mathrm{a}$ \\
& 5000 & $18,93 \mathrm{a}$ \\
& 10.000 & $7,84 \mathrm{~b}$ \\
Bisma & 0 & $22,8 \mathrm{a}$ \\
& 5000 & $19,25 \mathrm{~b}$ \\
\hline \hline
\end{tabular}

Tabel 5

Analisis Pengaruh Interaksi Variasi Konsentrasi $\mathrm{NaCl}$ terhadap berat basah Z. mays

\begin{tabular}{ccc}
\hline \hline Varietas & $\begin{array}{c}\text { Konsentrasi NaCl } \\
(\mathrm{ppm})\end{array}$ & $\begin{array}{c}\text { Pertambahan Berat } \\
\text { Basah }\end{array}$ \\
\hline Srikandi Kuning & 0 & $7,126 \mathrm{a}$ \\
& 5000 & $5,12 \mathrm{~b}$ \\
Bisma & 10.000 & $2,38 \mathrm{c}$ \\
& 0 & $6,51 \mathrm{a}$ \\
& 5000 & $4,98 \mathrm{~b}$ \\
\hline \hline
\end{tabular}

Tabel 6 .

Analisis Pengaruh Interaksi Variasi Konsentrasi $\mathrm{NaCl}$ terhadap berat kering Z. mays

\begin{tabular}{ccc}
\hline \hline Varietas & $\begin{array}{c}\text { Konsentrasi NaCl } \\
(\mathrm{ppm})\end{array}$ & $\begin{array}{c}\text { Pertambahan berat } \\
\text { kering }\end{array}$ \\
\hline \multirow{2}{*}{ Srikandi Kuning } & 0 & $0,36 \mathrm{a}$ \\
& 5000 & $0,28 \mathrm{ab}$ \\
& 10.000 & $0,16 \mathrm{~b}$ \\
Bisma & 0 & $0,3633 \mathrm{a}$ \\
& 5000 & $0,24 \mathrm{~b}$ \\
\hline \hline
\end{tabular}

Keterangan: Pada tabel 2, 3, 4, 5 dan 6 huruf yang sama menunjukkan tidak berbeda nyata berdasarkan uji Tukey dengan tingkat kepercayaan $95 \%(\alpha=0,05 \%)$. 
Varietas tanaman yang memiliki pertambahan tinggi tanaman yang terendah adalah pada konsentrasi $\mathrm{NaCl}$ tertinggi, yaitu $10.000 \mathrm{ppm}$. Varietas Zea mays Srikandi Kuning dan Bisma, memiliki pertambahan tinggi tanaman yang tertinggi pada konsentrasi $\mathrm{NaCl} 0 \mathrm{ppm}$. Pengaruh salinitas terhadap tanaman tergantung pada jenis dan varietas tanaman. Setiap jenis dan varietas tanaman mempunyai ketahanan yang berbeda dalam pertahanan terhadap cekaman. Pada varietas Srikandi Kuning konsentrasi 0 ppm mempunyai rata-rata pertumbuhan tinggi tanaman $23,143 \mathrm{~cm}$, konsentrasi 5000 ppm rata-rata pertumbuhan tinggi tanaman $18,64 \mathrm{~cm}$, konsentrasi $10.000 \mathrm{ppm} 7,73 \mathrm{~cm}$. Pada varietas Bisma konsentrasi 0 ppm rata-rata pertumbuhan tinggi tanaman 24,516 cm, konsentrasi 5000 ppm rata-rata pertumbuhan tinggi tanaman 19,443 cm, konsentrasi 10.000 ppm rata-rata pertumbuhan tinggi tanaman $5,76 \mathrm{~cm}$. Hal ini menunjukkan bahwa meningkatnya konsentrasi salinitas menurunkan pertumbuhan tinggi tanaman [7].

Penurunan tinggi tanaman dapat disebabkan karena terbatasnya persediaan air dan bahan organik dalam jaringan karena pengaruh salinitas. Penurunan jumlah air menyebabkan sel kehilangan turgor sehingga terdapat kecenderungan bagi plasmalema untuk lepas dari dinding sel (plasmolisis) [7]. Pada proses pemanjangan sel, tanaman memerlukan keseimbangan air yang sesuai karena kekuatan pemanjangan sel merupakan akibat dari tekanan turgor. Adanya air akan meningkatkan turgor dinding sel yang mengakibatkan dinding sel mengalami peregangan sehingga ikatan antara dinding sel melemah. Hal inilah yang mendorong dinding dan membran sel bertambah besar, sehingga minimnya ketersediaan air akan menghambat pertumbuhan tanaman [14].

Pada pengujian ketahanan tanaman jagung dengan perlakuan $\mathrm{NaCl}$ menunjukkan bahwa luas daun (Tabel 3) semakin menurun dengan semakin meningkatnya konsentrasi $\mathrm{NaCl}$ yang diberikan. dengan tingkat penghambatan terhadap pertumbuhan luas daun yang berbeda-beda yaitu konsentrasi 0 ppm dengan 5000 ppm dan 10.000 ppm pada semua varietas. Semakin tinggi konsentrasi pada perlakuan salinitas maka luas daun tanaman akan semakin menurun (Tabel 3). Luas daun pada konsentrasi 0 ppm menunjukkan kenaikan yang signifikan kemudian turun dengan pertambahan tingkat salinitas seperti yang terlihat pada Tabel 3. Hal ini menunjukkan laju pertumbuhan daun dan luas daun berbanding terbalik dengan kenaikan salinitas. Luas daun berperan penting dalam proses fotosintesis, bahwa semakin luas daun tersebut maka semakin besar cahaya yang diserap daun dalam proses fotosintesis, fotosintesis yaitu pembentukan karbohidrat. Karbohidrat merupakan energi yang dibutuhkan untuk metabolisme dalam tanaman [7]. Penurunan luas daun diduga disebabkan oleh adanya pengaruh salinits terhadap osmotik yang menyebabkan tanaman sulit menyerap air dan pengaruh dari ion $\mathrm{Na}$ dan $\mathrm{Cl}$, sehingga pembelahan dan pembesaran sel terhambat. Jumlah daun menunjukkan penurunan yang nyata disebabkan oleh terlarutnya garam sehingga menurunkan potensial air yang berakibat tanaman sulit untuk menyerap air dan proses pertumbuhannya tidak normal sebagai contoh pembentukan dan pembesaran sel-sel yang mempengaruhi luas daun dan mengakibatkan penuaan daun sehingga terjadi pengurangan jumlah daun.
Varietas Srikandi Kuning dan Bisma memiliki pertambahan berat basah yang terendah adalah pada konsentrasi $\mathrm{NaCl}$ tertinggi, yakni 10.000 ppm Srikandi kuning 2,38 gram dan Bisma 1,91 gram. Srikandi Kuning maupun Bisma, memiliki bobot berat basah yang tertinggi pada cekaman $\mathrm{NaCl} 0$ ppm. Penurunan berat basah disebabkan jumlah air yang masuk ke akar tanaman akan berkurang karena makin tingginya konsentrasi garam. Adanya garam mengakibatkan peningkatan transpirasi. Peningkatan laju transpirasi akan menurunkan jumlah air tanaman sehingga tanaman menjadi layu. Hal inilah yang menyebabkan berat basah menurun [15]. Biomassa tanaman pada penelitian mencerminkan hasil fotosintesis bersih (net photosynthesis) yang terkait dengan ketersediaan nutrien yang dapat diserap oleh tanaman [10]. Bobot berat basah tanaman merupakan ukuran yang paling sering digunakan untuk menggambarkan dan mempelajari pertumbuhan tanaman. Ini didasarkan atas kenyataan bahwa taksiran tersebut relatif mudah diukur, sehingga komponen ini merupakan indikator pertumbuhan yang paling representatif apabila tujuan utamanya adalah mendapatkan penampilan keseluruhan tanaman atau suatu organ tertentu

Varietas tanaman yang memiliki pertambahan panjang akar yang terendah adalah pada konsentrasi $\mathrm{NaCl}$ tertinggi, yakni 10.000 ppm Srikandi kuning 7,84 cm dan Bisma 4,53 cm. Varietas Srikandi Kuning maupun Bisma, memiliki pertambahan panjang akar yang tertinggi pada cekaman $\mathrm{NaCl}$ 0 ppm. Salinitas dalam konsentrasi yang tinggi menyebabkan penghambatan panjang akar dikarenakan salinitas tanah yang tinggi dengan kandungan ion $\mathrm{Na}^{+}$dan $\mathrm{Cl}^{-}$tinggi akan meracuni tanaman dan meningkatkan $\mathrm{pH}$ tanah yang mengakibatkan berkurangnya ketersediaan unsur-unsur hara mikro [10]. Demikian pula dengan hasil penelitian bahwa salinitas menyebabkan penurunan secara drastis terhadap konsentrasi ion Fe di daun maupun akar pada tanaman gandum (barley). Penurunan tersebut disebabkan karena berkurangnya penyerapan Fe pada kondisi salinitas tinggi [4].

Varietas tanaman yang memiliki pertambahan berat kering yang terendah adalah pada konsentrasi $\mathrm{NaCl}$ tertinggi, yakni 10.000 ppm Srikandi kuning 0,16 gram dan Bisma 0,11 gram. Baik Srikandi Kuning maupun Bisma, memiliki pertambahan berat kering yang tertinggi pada cekaman $\mathrm{NaCl} 0$ ppm. Dari Tabel.6 diketahui bahwa rerata berat kering tanaman jagung pada konesntrasi $\mathrm{NaCl} 0 \mathrm{ppm}$ lebih tinggi daripada tanaman jagung padakonsentrasi 5000 ppm dan 10.000 ppm. Respon tanaman terhadap perlakuan salinitas yang ditunjukkan oleh berat kering menurun dengan meningkatnya tingkat salinitas. Pemberian konsentrasi garam (salinitas) menyebabkan jumlah air dalam tanaman berkurang sehingga turgor sel-sel penutup stomata turun. Penurunan turgor stomata mengakibatkan proses fotosintesis terhambat sehingga jumlah asimilat yang dihasilkan oleh tanaman semakin berkurang dan proses respirasi meningkat sehingga berat kering tanaman menjadi menurun [11]. Salinitas yang tinggi akan menyebabkan proses respirasi dan fotosintesis menjadi tidak seimbang. Apabila proses respirasi lebih besar dari pada fotosintesis maka berat kering tanaman semakin berkurang [16]. 


\section{KESIMPULAN}

Kesimpulan penelitian ini adalah konsentrasi $\mathrm{NaCl}$ berpengaruh nyata terhadap pertumbuhan Zea mays varietas Bisma dan Srikandi Kuning.Tingkat ketahanan morfologi Zea mays varietas Srikandi Kuning dan Bisma terhadap tingginya konsentrasi $\mathrm{NaCl}$ berbeda. Varietas Srikandi Kuning menunjukkan lebih toleran dibandingkan varietas Bisma. Hasil cekamaan $\mathrm{NaCl}$ terendah terjadi pada konsentrasi 10.000 ppm yaitu tinggi tanaman Srikandi Kuning 7,73 cm dan Bisma 5,76 $\mathrm{cm}$, luas daun $11,98 \mathrm{~mm}^{2}$ dan bisma $11,98 \mathrm{~mm}^{2}$, berat basah Srikandi Kuning 2,38 gram dan Bisma 1,91 gram, berat kering Srikandi Kuning 0,16 gram, panjang akar Srikandi Kuning $7,84 \mathrm{~cm}$ dan Bisma 4,53 cm.

\section{DAFTAR PUSTAKA}

[1] M. Ardiansyah, M. Lisa, and R. Nini, "Respons Pertumbuhan dan Produksi Kedelai Hasil Seleksi Terhadap Pemberian Asam Askorbat dan Inokulasi Fungi Mikoriza Arbuskular di Tanah Salin," J. Online Agroekoteknologi, vol. 2, no. 3, pp. 948-954, 2014.

[2] Balkrisna and M. dam Shande, Ilmu Kesuburan Tanah. Jakarta: Kanisius, 2013.

[3] D. Ding, L. Zhang, H. Wang, Z. Zhang, and Y. Zheng, "Differential Expression of MiRNAs in Response to Salt Stress in Maize Roots," Ann. Bot., vol. 103, pp. 29-38, 2009.

[4] A. D. Dooki, P. F. Mayer, H. Askari, A. A. Zaiee, and G. H. Salekdeh, "Proteomic Responses of Rice Young Panicles to Salinity," Proteomics, vol. 6, pp. 6498-6507.
[5] A. E. El-Meleigy, F. G. Mahdia, H. M. Fouad, and A. I. Mona, "Responses to $\mathrm{NaCl}$ Salinity of Tomato Cultivated and Breeding Lines Differing in Salt Tolerance in Callus Cultures," Int. J. Agric. Biol., vol. 6, no. 61, pp. 1560-8530, 2004.

[6] J. T. Flowers, "Improving Crop Salt Tolerance," J. Exp. Bot, vol. 396, no. 55, pp. 307-319, 2004.

[7] P. R. Goldsworthy and N. M. Fisher, Fisiologi Tanaman Budidaya Tropik. Yogyakarta: Universitas Gadjah Mada Press, 1992.

[8] F. Huang, S. Fulda, M. Hagermann, and B. Norling, "Proteomic Screening of Salt-Stress-Induced Changes in Plasma Membranes of Synechocystis sp. strain PCC6803," Proteomics, vol. 6, pp. 910-920, 2006.

[9] Jakab, S. G., and F. Riandy, "Response and Adaptation 14 day by Plants to Salinity Stress," Ann. Bot., vol. 96, pp. 501-505.

[10] K. Kosova, I. T. Prail, and P. Vitamvas, "Protein Contribution to Plant Salinity Response and Tolerance Acquisition," Internaltional J. Mol. Sci., vol. 14, pp. 6757-6789.

[11]J. K. Zhu, "Salt and drought stress signal transduction in plants," Аnпи. Rev Plant Biol, vol. 53, pp. 247-273, 2002.

[12]D. K. Welsh and H.C. Minor, Agronomic Characteristic and Environmental Stress. In A G. Norman (Eds) Soybean: Phsiology, Agronomy, and Utilization. New York: Academic Press, 1991.

[13]T. Saputro, N. Fadillatus., and E. Dini, "Dynamics Expression Of Osr40c1 Gene And Growth Of Maize (Zea Mays) Calluses In Responding To Salt Stress," Biodiversitas, vol. 18, no. 2, pp. 801-808, 2017.

[14]F. . Salisbury and C. W. Ross, Plant Physiology, 4th ed. California: Wadsworth Publishing Company, 1995.

[15]N. Sholihah and T. Saputro, "In vitro selection of maize (Zea mays L.) varieties Talango and Manding to Salinity Stress," J. Sains dan Seni ITS, vol. 4, no. 1, pp. E60-E63, 2015.

[16]Zhong and L. Lauvhi, "Effect of Calcium on the Emergence and Seedling of Tomatoes Grown in Salty Growing Media Conditions," J. Agric. Sci, vol. 12, pp. 53-57, 1994. 